\title{
The Influence of Wait on Physical Chemistry and Microbiology on Melted Foods Hospital Formula and Commercial Formula In RS.RK Charitas Palembang
}

\author{
$1^{\text {st }}$ Khusnul Alifia Arrizki \\ Nutrition Department \\ Poltekkes Kemenkes Palembang \\ Palembang, Indonesia \\ alifiakhusnul04@gmail.com
}

\author{
$2^{\text {nd }}$ Yuli Hartati \\ Nutrition Department \\ Poltekkes Kemenkes Palembang \\ Palembang, Indonesia \\ yuli.hartati@poltekkespalembang.ac.id
}

\author{
$3^{\text {rd }}$ Sartono \\ Nutrition Department \\ Poltekkes Kemenkes Palembang \\ Palembang, Indonesia \\ sartonogz@gmail.com
}

Corresponding author: yuli.hartati@poltekkespalembang.ac.id

\begin{abstract}
Liquid food is food that has liquid consistency given to critical patients (acute infection, very high fever, very low appetite, stroke, unable to chew and difficult to swallow). Types of liquid foods are clear liquid foods, full liquid foods, and thick liquid foods. The purpose of feeding in liquid form that meets nutritional needs[1]. Damage to liquid food formulas can cause these foods are not safe for consumption if they are already contaminate. Microbiological tests are needed to determine the quality and durability and detect the number of microbes present in the liquid food. Besides it is also necessary, physical tests (color, and viscosity) and chemical tests (test proximate and $\mathrm{pH}$ ). The purpose of this research is to find out the infulence of wait on physical, chemistry and microbilogy on melted foods hospital formula and commercial formula. This research is a quasiexperimental study using a cross- sectional research design and repeated ANOVA data analysis. The result in physical, chemical tests that there is no effect of waiting time on physical and chemical properties in hospital and commercial liquid food formulas in RS Charity Hospital Palembang with colors $L * a * b(p>0.005)$, viscosity ( $p>$ $0.005)$, pH ( $>>0.005)$. In the microbiology test with ( $<<$ 0.005) that there is an influence of waiting time on the physical and chemical properties of liquid food in the hospital and commercial formulas in RS.RK Charitas Palembang. The conclusion there is no influence of wait on color, viscosity, $\mathrm{pH}$ on melted foods hospital formula and commercial formula. There is influence of wait on microbiology on melted foods hospital formula and commercial formula in RS.RK Charitas Palembang
\end{abstract}

Keywords: Liquid food, physical, chemistry, microbiology.

\section{INTRODUCTION}

Liquid food is food supplied to vital patients that has a liquid consistency (acute infection, extremely high fever, extremely low appetite, stroke, inability to chew and trouble swallowing). Simple liquid food, full liquid food, and dense liquid food are classes of liquid food. The aim of providing food that meets nutritional needs in liquid form [1].

One way of satisfying nutrition via the digestive tract, either orally or with the aid of a system (tube), is nutritional assistance through delivering enteral formulas or liquid diets. There are 2 types of enteral formulas, namely hospital-made enteral formulas and commercial formulas, that are mostly used in hospitals[2]. Enteral formulas made by hospitals are more affordable than industrial formulas. In the planning process, both of these formulas must always pay attention to hygiene variables.

If it is infected, damage to liquid formula food will make the food unsafe for consumption [3]. Therefore, liquid formula food should be eaten immediately after cooking because the amount of microorganisms and the consistency of the enteral formula itself would be compromised if left for a long time and at room temperature for more than 3 hours [2]. Since liquid formula food is a liquid food that is suitable for the 
growth of microorganisms that come from the composition of ingredients, preparation during manufacturing and transport, or from the hospital itself, the process of producing this formula goes through many stages of processing that are susceptible to the dangers of microorganism contamination [4].

With ingredients that contain high nutrients, liquid food has ample nutritional content. Based on the ingredients used in the manufacturing of liquid food formulas for both hospital and commercial formulas, it can be shown that microorganisms, with a high nutritional formula content, can use these nutrients to grow and replicate and harm the quality of the liquid food formula. In addition, perishable food products are the products used. To determine the quality and durability and detect the number of microbes present in these liquid foods, microbiological tests are needed. Furthermore, physical (color and viscosity) and chemical (proximate and $\mathrm{pH}$ ) tests are also required.

\section{RESEARCH METHODOLOGY}

The research is quasi-experimental study to evaluate the changes based on waiting time in the physical, chemical and microbiological properties of hospital formula liquid food and commercial formula liquid food. The research was carried out in December 09-16 2019. Liquid formula food made in the hospital in the UST (Stroke Unit) room with a special formula for the stroke diet is the sample to be tested. 135 grams of liquid food extracted from hospital formulas and 200 grams of consumer formulas were the amount of samples to be analyzed. With the total plate count (ALT) process, to test the number of germs was carried out at Microbiology Laboratory of the Nutrition Department of the Palembang Health Polytechnic. Viscosity testing using an instrument, a viscometer in particular, color reading with a color reader (CS-10), while $\mathrm{pH}$ uses a pHmeter ( $\mathrm{pH}-224)$ was carried out at the Food Laboratory of the Nutrition Department of the Palembang Health Polytechnic, a close test to see the macro nutritional value was carried out at the Chemical and Microbiology Laboratory of the Faculty of Agriculture, Sriwijaya University Palembang.

The data was collected by physical, chemical and microbiological test measurements, while the waiting period was observed by recording the waiting time and performing hospital data interviews with the hospital. The effect of independent variables like waiting time on the dependent variable, namely physical properties (color and viscosity), chemistry (proximate and $\mathrm{pH}$ tests), microbiology (germ count), was analyzed using the repeated anova test.

\section{RESULTS}

Waiting time observation showed that the time interval from after processing to the time of distribution was 41 minutes, while the distance of distribution to the patient room was 81 minutes. The waiting period therefore begins after manufacturing, delivery time, and enters the patient space. They are put in the pantry first before entering the patient's room. The results of physical, chemical and microbiological property measurements dependent on the waiting period are shown in the following table.

Table 1. Color Value L (Light / Dark)

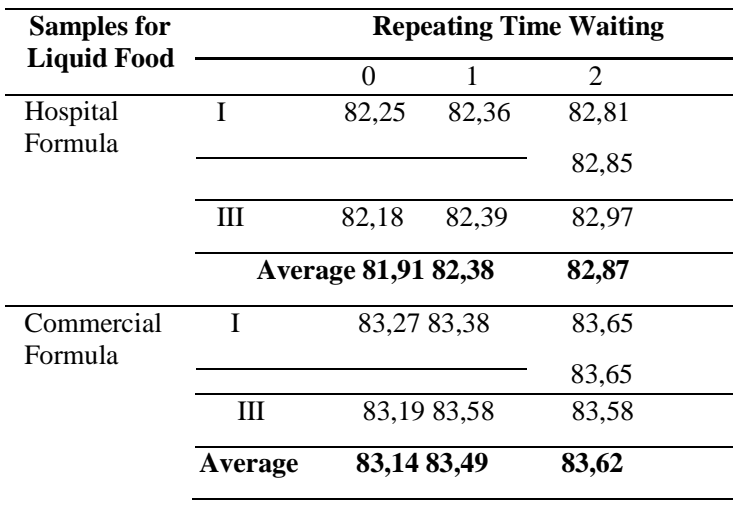

Table 2. Color Value a * (Green / Red $)$

\begin{tabular}{|c|c|c|c|}
\hline \multirow{2}{*}{$\begin{array}{l}\text { Samples for } \\
\text { Liquid Food }\end{array}$} & & \multicolumn{2}{|c|}{ Repeating Time Waiting } \\
\hline & & 0 & 2 \\
\hline \multirow{4}{*}{$\begin{array}{l}\text { Hospital } \\
\text { Formula }\end{array}$} & $\mathrm{I}$ & $-4,41 \quad-7,52$ & $-4,15$ \\
\hline & II & $-3,83-4,14$ & $-6,36$ \\
\hline & III & $-4,25-4,14$ & $-6,18$ \\
\hline & Average & $1,07-5,27$ & $-5,56$ \\
\hline \multirow{4}{*}{$\begin{array}{l}\text { Commercial } \\
\text { Formula }\end{array}$} & I & $-6,13-6,02$ & $-5,86$ \\
\hline & II & $-6,18$ & $-5,86$ \\
\hline & III & $-6,10$ & $-6,01$ \\
\hline & Average & $-6,14 \quad-6,0-$ & $-5,91$ \\
\hline
\end{tabular}

Table 3. Color Value b* (Yellow / Blue)

\begin{tabular}{lllcc}
\hline $\begin{array}{l}\text { Samples } \\
\text { for Liquid } \\
\text { Food }\end{array}$ & \multicolumn{4}{l}{ Repeating Time Waiting } \\
\cline { 2 - 5 } $\begin{array}{l}\text { Hospital } \\
\text { Formula }\end{array}$ & I & 1,91 & 2,82 & 1,78 \\
\cline { 2 - 5 } & II & 1,84 & 1,74 & 2,67 \\
\cline { 2 - 5 } & III & 1,82 & 1,74 & 2,71 \\
\hline \multirow{2}{*}{$\begin{array}{llll}\text { Fommercial } \\
\text { Formula }\end{array}$} & I & 3,81 & 2,75 & 2,81 \\
\cline { 2 - 5 } & II & 2,71 & 2,65 & 2,81 \\
\cline { 2 - 5 } & III & 2,79 & 2,63 & 2,63 \\
\hline & Average & $\mathbf{3 , 1 0}$ & $\mathbf{2 , 6 8}$ & $\mathbf{2 , 7 5}$ \\
\hline
\end{tabular}


Table 4. The Liquid Food Viscosity Value at RS.RK Charitas Palembang

\begin{tabular}{llccc}
\hline Samples for & \multicolumn{4}{c}{ Repeating Time Waiting } \\
\cline { 2 - 5 } Liquid Food & & 0 & 1 & 2 \\
\hline Hospital & I & 5,9 & 5,9 & 6,0 \\
\cline { 2 - 5 } Formula & II & 5,9 & 6,2 & 5,6 \\
\cline { 2 - 5 } & III & 5,8 & 5,9 & 5,6 \\
\cline { 2 - 5 } & Average & $\mathbf{5 , 9}$ & $\mathbf{6 , 0}$ & $\mathbf{5 , 7}$ \\
\hline Commercial & I & 6,2 & 6,5 & 6,3 \\
\cline { 2 - 5 } Formula & II & 6,6 & 6,2 & 6,4 \\
\cline { 2 - 5 } & III & 6,2 & 6,3 & 5,0 \\
\cline { 2 - 5 } & Average & $\mathbf{6 , 3}$ & $\mathbf{6 , 3}$ & $\mathbf{6 , 2}$ \\
\hline
\end{tabular}

Table 5. Liquid food $\mathrm{pH}$ worth at RS.RK Charitas Palembang

\begin{tabular}{llccc}
\hline \multicolumn{1}{c}{$\begin{array}{l}\text { Samples for } \\
\text { Liquid Food }\end{array}$} & \multicolumn{4}{c}{ Repeating Time Waiting } \\
\cline { 2 - 5 } $\begin{array}{l}\text { Hospital } \\
\text { Formula }\end{array}$ & I & 6,73 & 6,64 & 6,57 \\
\cline { 2 - 5 } & II & 6,52 & 6,50 & 6,50 \\
\cline { 2 - 5 } & III & 6,46 & 6,52 & 6,44 \\
\cline { 2 - 5 } & Average & $\mathbf{6 , 5 7}$ & $\mathbf{6 , 5 5}$ & $\mathbf{6 , 5 0}$ \\
\hline Commercial & I & 7,30 & 7,28 & 7,25 \\
\cline { 2 - 5 } Formula & II & 7,15 & 7,15 & 6,90 \\
\cline { 2 - 5 } & III & 6,89 & 6,87 & 7,10 \\
\cline { 2 - 5 } & Average & $\mathbf{7 . 1 1}$ & $\mathbf{7 . 1 0}$ & $\mathbf{7 . 0 8}$
\end{tabular}

Table 6. Liquid Food Germs Worth Dependent on Waiting Period at RS.RK. Palembang Charitas

\begin{tabular}{llll}
\hline $\begin{array}{l}\text { Samples for } \\
\text { Liquid Food }\end{array}$ & \multicolumn{3}{c}{$\begin{array}{c}\text { Time } \\
\text { Waiting }\end{array}$} \\
\cline { 2 - 4 } & & \multicolumn{3}{c}{1 2 } \\
\hline $\begin{array}{l}\text { Hospital } \\
\text { Formula }\end{array}$ & $0,14 \times$ & $0,66 \times$ & $1,36 \times$ \\
\hline Commercial & & & \\
Formula & $0,15 \times$ & $0,62 \times$ & $1,33 \times$ \\
\hline
\end{tabular}

Table 7. Impact on liquid Home formulas' nutritional value and commercial liquid foods

\begin{tabular}{lll}
\hline \multicolumn{1}{c}{$\begin{array}{c}\text { Samples for } \\
\text { Liquid Food }\end{array}$} & \multicolumn{2}{c}{ Worth of nutrition } \\
\hline & \multicolumn{1}{c}{$\begin{array}{c}\text { Worth of } \\
\text { nutrition }\end{array}$} & \multicolumn{1}{c}{$\begin{array}{c}\text { Laboratory Tests' } \\
\text { nutritional value }\end{array}$} \\
\cline { 2 - 3 } & \multicolumn{1}{c}{$\mathrm{E}: 402 \mathrm{kkal}$} & $\mathrm{E}: 522,44 \mathrm{kkal}$ \\
\hline $\begin{array}{l}\text { Hospital } \\
\text { Formula }\end{array}$ & $\mathrm{P}: 16,98 \mathrm{~g}$ & $\mathrm{P}: 23,07 \mathrm{~g}$ \\
\cline { 2 - 3 } & $\mathrm{L}: 4,2 \mathrm{~g}$ & $\mathrm{~L}: 5,72 \mathrm{~g}$ \\
\cline { 2 - 3 } & $\mathrm{KH}: 83,5 \mathrm{~g}$ & $\mathrm{KH}: 94,67 \mathrm{~g}$ \\
\hline Commercial & $\mathrm{E}: 448,28 \mathrm{kkal}$ & $\mathrm{E}: 380,16 \mathrm{kkal}$ \\
\cline { 2 - 3 } & $\mathrm{P}: 17,24 \mathrm{~g}$ & $\mathrm{P}: 12,72 \mathrm{~g}$ \\
\cline { 2 - 3 } & $\mathrm{L}: 1,79 \mathrm{~g}$ & $\mathrm{~L}: 1,61 \mathrm{~g}$ \\
\cline { 2 - 3 } & $\mathrm{KH}: 63,79 \mathrm{~g}$ & $\mathrm{KH}: 80,71$ \\
\hline
\end{tabular}

Table 8. Impact on liquid food of waiting time

\begin{tabular}{|c|c|c|c|c|c|c|}
\hline $\begin{array}{c}\text { Time } \\
\text { waiting }\end{array}$ & $\mathbf{L}$ & $a^{*}$ & $\mathbf{b}^{*}$ & $\begin{array}{c}\text { viscos } \\
\text { ity }\end{array}$ & pH & $\begin{array}{c}\text { The } \\
\text { Bacte } \\
\text { ria } \\
\text { Num } \\
\text { ber }\end{array}$ \\
\hline $\begin{array}{l}\text { After } \\
\text { processi } \\
\text { ng } \\
\text { Distribu } \\
\text { tion } \\
\text { Patient } \\
\text { room }\end{array}$ & 0,205 & 0,562 & 0,154 & 0,285 & 0,245 & 0,014 \\
\hline
\end{tabular}

\section{DISCUSSION}

Using an instrument, namely colorimetry, the color value is known, where the $\mathrm{L}^{*} \mathrm{a} * \mathrm{~b}$ value appears in the form of a number that displays the color of liquid food for hospital formulas and commercial formulas. In liquid foods, the importance of L (brightness), a (reddish / greenish) and b (yellowish / bluish) [4]. Measurement meaning $\mathrm{L} *$ denotes the degree of lightness or darkness $(\mathrm{L} *=0$ denotes perfect black and $\mathrm{L} *=100$ denotes perfect white); $\mathrm{a} *$ denotes redness or greenness and $\mathrm{b} *$ denotes yellowish or bluish [5]. The greater the value, the brighter or whiter the color would be.

The color of this liquid food is the product of fat globules and colloidal particles of casein and calcium phosphate dispersing from light reflection. The reddish yellow color is due to the fat and carotene content that is dissolved in it. Additional oil is provided in the hospital formula liquid food that can raise the fat content in the hospital formula liquid food so that the color shows a reddish a * value higher than the commercial formula liquid food. Additional oil that can raise the fat content in the hospital formula liquid food is included in the hospital formula liquid food so that the color shows a reddish a * value higher than the commercial formula liquid food. The color for hospital and commercial formulations in liquid food formulations at value $\mathrm{b}$ is in the range of bluish color, which means that the fat content in it has been decreased. The higher the $\mathrm{b} *$ amount, the greater the reduction in the liquid food fat content [6].

Hospital and commercial food quest formulas provide statistical test results on color values, i.e. the physical properties (color) of liquid food formulas for hospital and commercial formulas are not influenced by waiting time at RS.RK Charitas Palembang. The lack of impact of waiting time on color is affected, one of which is that there is no alteration in the substances found in 
liquid food that can cause color changes. The limited number of samples tested is another thing which affects the results of the statistical tests carried out, so the results obtained are less reliable [7].

After conditions tend to be stable, the resulting viscosity is the number that appears on the viscometer screen. Liquid food or enteral food with a liquid texture is very beneficial for patients, particularly those of whom experience chewing, swallowing and digestion problems. Furthermore, giving liquid or enteral food may also sustain biologically functioning gastrointestinal functions.

Several variables affect the viscosity value of fat temperature, concentration and state, as well as protein concentration and state[8,14]. High protein levels can increase the viscosity of. The greater the solid concentration in a product, the lower or thicker the viscosite value. Due to an acidic environment during the fermentation process, viscosity may be generated because the protein in milk has reached the isoelectric point so that the protein coagulates [8].

In hospital formulas and commercial formulas with statistical values $(p>0.05)$, the findings of statistical viscosity tests showed that there was no improvement in the waiting period for viscosity. Hospital formula liquid food on observation of different $\mathrm{pH}$ from after processing, delivery to patient rooms. The hospital formula after processing has an average $\mathrm{pH}$ of 6.57 in the observation of liquid food, which is in the good category, since the $\mathrm{pH}$ range is good, namely 6.5-6.7 $\mathrm{pH}$, this goes into acidic $\mathrm{pH}$. This is affected by the liquid food material, namely the lactose presence that transforms into lactic acid that naturally exists in liquid formula-based foods due to the activity of bacteria that can break down lactose into lactic acid. $\mathrm{pH}$ can be decreased by the behavior of microorganisms that produce lactic acid [9].

On observation from post-processing, the commercial formula liquid food has an average $\mathrm{pH}$ of 7.11, even in the alkaline $\mathrm{pH}$ group since the $\mathrm{pH}$ value is $>7$. This commercial formula is not natural or not appropriate when compared to the normal $\mathrm{pH}$ of milk-based liquid foods of 6.5 to $6.7 \mathrm{pH}$ in liquid food. This is caused by the formula's lactose content. There is less lactose in this commercial liquid food formula than in hospital formulations, so that the transition from lactose to lactic acid happens more slowly or longer. For the hospital as a whole, the $\mathrm{pH}$ value of the liquid food formula is classified as good since the $\mathrm{pH}$ value is in the 6.5-6.7 range. The results of the statistical test $p>0.005$ showed that waiting time had little effect on $\mathrm{pH}$ because lactose, broken down into lactic acid, did not dramatically affect the $\mathrm{pH}$ of liquid foods.

Liquid food is food that has a consistency of liquid and thick. This food is given to patients who have trouble chewing, swallowing, and digesting food caused by decreased consciousness, high temperature, nausea, vomiting, post gastrointestinal bleeding, and pre and post surgery. There are variations in nutritional value in hospital formulas and commercial formulas measured in hospital laboratory studies. A serving size of $135 \mathrm{~g}$ by weight of hospital formula and $100 \mathrm{~g}$ by weight of commercial formula are accounted for by nutritional value. Patients who were given the studied liquid food were patients in the UST (Stroke Unit) bed. In order to enhance the nutritional condition of the patient, the hospital formula liquid food is then prepared with a particular composition for patients in the bed. Meanwhile, the industrial liquid food formula is developed in other rooms in the same manner as the patient, with the exception of patients who have a special diet due to the disease of the patient, specifically one patient with a low protein diet.

Measurement using the ALT (plate number method) method of the number of these germs. A sequence of dilutions is used in this technique and the planting is performed in agar. The germ count measurement was carried out for a total of $2 \times 24$ hours after incubation. The number of germs in liquid food formula is not greater than $5 \mathrm{x}$ colonies / $\mathrm{ml}$ [10]. The findings of statistical germ number tests $(\mathrm{p}<0.05)$ show that there is a change in the number of germs in the home formula of liquid food waiting time. Pain and exchange formulas. Several factors can affect the high value of TPC in enteral formulas, one of which is that the ingredients used are rich in nutrients that are a means of growing and reproducing microorganisms. The high water activity found in enteral formulas in order for these microorganisms to grow and evolve is another factor influencing the growth of microorganisms. The temperature, water content, $\mathrm{pH}$, osmotic pressure, oxygen, light (light), and the character of the surrounding microbes are factors that influence bacterial growth [3].

\section{CONCLUSION}

There is an influence of waiting time on germ numbers in hospital formulas and commercial formulas, and there is no effect on color, viscosity and $\mathrm{pH}$ on waiting time. 


\section{ACKNOWLEDGMENT}

The author is gratefully, to especially those who helped me with research and RS.RK Charitas Palembang Hospital for giving me permission to do this research.

\section{REFERENCES}

[1] Lestari Dwin. Sifat Fisik, Ph dan Angka Kuman Makanan Cair Formula Rumah Sakit dan Formula Komersial Berdasarkan Waktu Tunggu di Rsudmuntilan Kabupatenmagelang. Poltekes Kemenkes Yogyakarta 2017:1-10.

[2] Hapsari HTP. Pengendalian Mutu Dalam Proses Pembuatan Makanan Enteral Di Rumah Sakit Dustira Kota Cimahi, Jawa Barat 2012:2.

[3] De Leeuw IH, Vandewoude MF. Bacterial contamination of enteral diets. Gut 1986;27:56-7. https://doi.org/10.1136/gut.27.Suppl_1.56.

[4] Fessler T. Blenderize Fooda For Home Tube Feeding: Learn About The Benefit, Risks, and Strategies for Succes. Today'sn Dietitien 2015; Vol. 17 No.

[5] Pelaes Vital AC, Goto PA, Hanai LN, Gomes-da-Costa SM, de Abreu Filho BA, Nakamura CV, et al. Microbiological, functional and rheological properties of low fat yogurt supplemented with Pleurotus ostreatus aqueous extract. LWT - Food Sci Technol 2015;64:1028-35. https://doi.org/10.1016/j.1wt.2015.07.003.

[6] Zhou Y, Wang JW, Jiang R, Yao X, Yang B, Cai SZ, et al. Study on anti- aging effect of ginsenoside $\mathrm{Rg} 1$ in serial transplantation of hematopoietic stem cells and progenitor cells. Zhongguo Zhongyao Zazhi 2013;38:2848- 53. https://doi.org/10.4268/cjcmm20131720.

[7] Pratiwi LE, Noer ER. Analisis Mutu Mikrobiologi dan Uji Viskositas Formula Enteral Berbasis Labu Kuning (Curcubita Moschata) Dan Telur Bebek. vol. 3. 2014. https://doi.org/10.14710/jnc.v3i4.6915.

[8] Safitri MF, Swarastuti A. Kualitas Kefir Berdasarkan Konsentrasi Kefir Grain. J Apl Teknol Pangan 2013;2:8792.

[9] Umar, Razali, Novita A. Derajat Keasaman Dan Angka Reduktase Susu Sapi Pasteurisasi Dengan Lama Penyimpanan Yang Berbeda. J Med Vet 2014;08:43-6.

[10] Semarang SMPN. Online di : http://ejournals1.undip.ac.id/index.php/jnc Journal of Nutrition College , Volume 3 , Nomor 4, Tahun 2014 2014;3:647-54. 